\title{
Consumer behaviour of young Polish singles - selected issues
}

\section{Zachowania konsumenckie polskich młodych singli - wybrane zagadnienia}

\author{
dr hab. Tomasz Zalega, prof. Uniwersytetu Warszawskiego \\ Uniwersytet Warszawski, Wydział Zarządzania \\ ORCID: 0000-0002-7488-1184 \\ e-mail: tomasz.zalega@wp.pl
}

\begin{abstract}
This article is a research exercise and provides some insight into the consequences of singlehood as an alternative form of family life among young people living in Poland, in the sphere of consumption. Its primary goal is to identify consumer behaviours of young people living alone. The study consists of two parts: theoretical and empirical. On the basis of a critical analysis of literature, the first one attempts to explain the notion of single. Subsequently, it sheds light on the scale of singlehood in Poland and in the world. The second, major part is empirical. The basis for conclusions is provided by the research material collected in the survey conducted in a sample of 826 young singles. This article seeks to provide some insight into consumer behaviour of young Polish singles based on the results of my research. The findings confirm that the young singles interviewed can be considered very active consumers. Over $3 / 4$ of them like shopping or like it very much and do it a few times a week. The greatest pleasure is derived from shopping by singles in the 24-29 age group, mostly women with higher education and most commonly living in cities of over 500 thousand inhabitants. The majority of young singles prefer shopping at large shopping centres, with bazaars, open-air markets and small corner shops being less popular. While shopping for food, young singles attach considerable importance to freshness, quality, origin and promotion of food products, whereas they care less about brand, advertising and complementarity of the offer. In the case of durable goods, they attach the greatest importance to quality, price, brand and utility of products, with other determinants (fashion, promotions, shopping location, product packaging, advertising, the possibility of standing out) being less significant.
\end{abstract}

Keywords

single, young people, consumer behaviour, consumption

Artykuł ma charakter badawczy i dotyczy uchwycenia konsekwencji zjawiska singlizacji społeczeństwa jako alternatywnej formy życia rodzinnego wśród osób młodych żyjących w Polsce, w sferze konsumpcji. Jego podstawowym celem jest uchwycenie zachowań konsumenckich polskich młodych singli na podstawie wyników badań własnych. Opracowanie składa z dwóch części: teoretycznej i empirycznej. W pierwszej z nich na podstawie krytycznej analizy literatury podjęto się próby wyjaśnienia pojęcia „singiel”, a następnie naświetlono skalę zjawiska singlizacji w Polsce i na świecie. Natomiast druga, zasadnicza część pracy ma charakter empiryczny. Podstawę wnioskowania stanowi materiał badawczy pozy- skany dzięki przeprowadzonym przez autora badaniom na próbie 826 osób młodych żyjących w pojedynkę. Wyniki badania potwierdzają, że badanych młodych singli uznać można za bardzo aktywnych konsumentów. Pond 3/4 z nich lubi bądź bardzo lubi robić zakupy i dokonuje ich kilka razy w tygodniu. Największą przyjemność zakupy sprawiają singlom z grupy wiekowej 24-29 lat, przeważnie kobietom, z wyższym wykształceniem i zamieszkałym najczęściej w miastach po- wyżej 500 tys. mieszkańców. Większość młodych singli preferuje robienie zakupów w dużych centrach handlowych, natomiast mniejszą popularnością cieszą się bazary, targowiska i małe sklepy osiedlowe. Przy zakupie produktów żywnościowych młodzi single dużą wagę przywiązują do świeżości, jakości, pochodzenia produktu i promocji, natomiast są mniej wrażliwi na markę produktu, reklamę oraz komplementarność oferty. Z kolei w przypadku zakupu dóbr trwałego użytku badani single największą wagę przywiązują do jakości, ceny, marki i walorów użytkowych produktu, natomiast pozo- stałe determinanty (moda, promocje, miejsce zakupu, opakowanie produktu, reklama, możliwość wyróżnienia) mają dla nich mniejsze znaczenie. 


\section{References}

Bauereiss, R. \& Bayer, H. (1995). Alleinstehende und Alleinlebende: Die "Singles" in der amtlichen Statistik. In H. Bertrman (Ed.), Das Individuum und seine Familie. Lebensformen, Familienbeziehungen und Lebensereignisse im Erwachsenenalter. Opladen: Leske Budrich Verlag. https://doi.org/10.1007/978-3-32295771-9_2

Chambers-Schiller, L. (1999). Singlehood. In P.N. Stearns (Ed.), Encyclopaedia of Social History. New York-London: Routledge.

Cohen, A. M. (2009). The emergence of a global generation. The Futurist, 43(1), 57-59.

Czernecka, J. \& Zalega, T. (2017). Seniorzy i single jako przykłady segmentów konsumentów charakterystycznych dla współczesnych społeczeństw. In M. Bartosik-Purgat (Ed.), Zachowania konsumentów. Globalizacja, nowe technologie, aktualne trendy, otoczenie spoleczno-kulturowe. Warszawa: Wyd. Naukowe PWN.

Czernecka, J. (2011). Wielkomiejscy single. Warszawa: Poltex.

Deml, S. (2009). Singles also Thema in der Familiensoziologie Stellenwert, Probleme und unterschiedliche Facetten in der sozialwissenschaftlichen Forschung. München: Grin Verlag.

Felcman, D. \& Koperski, Ł. (2010). Bycie singlem jako nowa koncepcja życia i alternatywa wobec małżeństwa. Roczniki Socjologii Rodziny (XX): Zalety $i$ wady bycia w rodzinie i poza rodzina, 73-92.

Gajda, J. (1987). Samotność i kultura. Warszawa: PWN.

Guerreschi, C. (2005). New addictions. Le nuove dipendenze. Internet, lavoro, sesso, cellulare e shopping compulsivo. Milano: Edizioni San Paolo.

GUS. (2018). Struktura ludności. Warszawa: GUS.

Hertel, J., Schütz, A., DePaulo, B. M., Morris, W. L., \& Stucke, T. S. (2007). She's single, so what? How are singles perceived compared to people who are married? Zeitschrift für Familienforschung, 19(2), 139-158.

Hillis, M. (1936). Live alone and like it: The classic guide for the single woman. Philadelphia: Temple University Press.

Hradil, S. (1995). Die "Single-Gesellschaft". München: C.H. Beck.

Kobielska, Z. (2009, January). Singel wymarzony klient. Fresh\&Cool Market. Retrieved from http://www. fcmarket.pl/sezam/182829.pdf

Kuklińska, K. L. (2012). Polskie singielki. Pteć kulturowa. Feminizm. Ponowoczesność. Internet. Warszawa: Difin.

Lubelska, K. (2006, 21 October). Pojedynczo. Polskich singli pomysły na życie. Polityka, 42(2576).

Palus, K. (2010). Zalety i wady życia w pojedynkę w percepcji młodych dorosłych nieposiadających partnera życiowego . Roczniki Socjologii Rodziny (XX): Zalety i wady bycia w rodzinie i poza rodzina, 55-72.

Paprzycka, E. \& Izdebski, Z. (2016). Single i singielki. Intymność i seksualność osób żyjących w pojedynkę. Warszawa: Difin.

Paprzycka, E. (2008). Kobiety żyjące w pojedynkę. Między wyborem a przymusem. Warszawa: Wyd. Akademickie Żak.

Rosenmayr, L. \& Kolland, F. (1997). Mein "Sinn" ist nicht dein "Sinn". Verbindlichkeit oder Vielfalt — Mehrere Wege im Singletum. In U. Beck (Ed.), Kinder der Freiheit. Auflage III. Frankfurt am Main: Suhrkamp Verlag.

Ruszkiewicz, D. (2008). Życie w pojedynkę - ucieczka od rodziny czy znak naszych czasów? Łódź: Wyd. WSHE.

Ruszkiewicz, D. (2009). Czy życie w pojedynkę jest rzeczywiście wyborem? Problemy Opiekuńczo-Wychowawcze, (3), 51-56.

Shostak, A. B. (1987). Singlehood. In M. Sussman \& S. Steinmetz (Eds.), Handbook of Marriage and the Family. New York: Plenum Press. https://doi.org/10.1007/978-1-4615-7151-3_13

Stein, P. J. (1976). Single. New Jersey: Prentice-Hall.

Stein, P. J. (1981a). Single Life: Unmarried adults in social context. New York: St. Martin's Press.

Stein, P. J. (1981b). Being single; understanding single adulthood. In J. Stimson \& A. Stimson (Eds.), Sociology: Contemporary readings. Itasca: Peacock Publishers.

Tulli, R. (1978). Jednoosobowe gospodarstwa domowe. Warszawa: Instytut Filozofii i Socjologii PAN.

Tymicki, K. (2001). Staropanieństwo i starokawalerstwo. Analiza zjawiska. Studia Socjologiczne, (4), 77-106.

Watters, E. (2003). Urban Tribes: A generation redefines friendship, family, and commitment. New York-London: Bloomsbury.

Williams, K. C. \& Page, R. A. (2011). Marketing to the generations. Journal of Behavioral Studies in Business, 3(3), 1-17.

Wrzesień, W. (2003). Jednostka - rodzina - pokolenie. Studium relacji międzypokoleniowych w rodzinie. Poznań: Wyd. Naukowe UAM.

Żurek, A. (2003). Osoby samotne jako zjawisko społeczne. Roczniki Socjologii Rodziny, XV, 123-136. 
MARKETING I RYNEK 4/2019 • JOURNAL OF MARKETING AND MARKET STUDIES 4/2019 